Spring 2010

\title{
Access to higher education for undocumented students: "Outlaws" of social justice, equity, and equality
}

\author{
Corinne Harmon \\ Glenda Carne \\ Kristina Lizardy-Hajbi \\ Eugene Wilkerson
}

Follow this and additional works at: https://digitalscholarship.unlv.edu/jpme

\section{Repository Citation}

Harmon, Corinne; Carne, Glenda; Lizardy-Hajbi, Kristina; and Wilkerson, Eugene (2010) "Access to higher education for undocumented students: "Outlaws" of social justice, equity, and equality," Journal of Praxis in Multicultural Education: Vol. 5: No. 1, Article 9.

DOI: $10.9741 / 2161-2978.1033$

Available at: https://digitalscholarship.unlv.edu/jpme/vol5/iss1/9

This Article is protected by copyright and/or related rights. It has been brought to you by Digital Scholarship@UNLV with permission from the rights-holder(s). You are free to use this Article in any way that is permitted by the copyright and related rights legislation that applies to your use. For other uses you need to obtain permission from the rights-holder(s) directly, unless additional rights are indicated by a Creative Commons license in the record and/ or on the work itself.

This Article has been accepted for inclusion in Journal of Praxis in Multicultural Education by an authorized administrator of Digital Scholarship@UNLV. For more information, please contact digitalscholarship@unlv.edu. 


\title{
Access to Higher Education for Undocumented Students: "Outlaws" of Social Justice, Equity, and Equality
}

\section{Corinne Harmon, Glenda Carne, Kristina Lizardy-Hajbi, and Eugene Wilkerson}

\begin{abstract}
The status of access to higher education for undocumented students in this country is inconsistent from state to state, region to region, and the nation at large. This inconsistency is reflected in the development of policies and legislation that either provide or limit access to an affordable higher education for these students. Beneath the external debates regarding the application of instate tuition rates for undocumented students exists an underlying struggle embedded within an inherent cultural, societal, and systemic bias around beliefs, power, and privilege.

The marginalization of undocumented students in accessing higher educationas evidenced by the absence of social justice, equity, and equality-has created an underground movement that is based in feminist and critical race theory descriptions of "outlaw culture." This framework encapsulates the phenomenon of outlaw culture within the confines of systemic barriers, whereby those in positions closest to the front lines of service and access to higher education may become "outlaws" in bending, breaking, or circumventing the rules and regulations that perpetuate inequity and inequality and inhibit a socially just process for undocumented students. Implications regarding policy and practices to address socially just, equitable, and equal processes for access to higher education for undocumented students are presented for future consideration.
\end{abstract}

\section{Introduction}

I graduated with honors [from high school]. I was so happy that I asked my counselor to help me to go to college. She told me that I was just another undocumented girl and that she could not help me. I insisted she help, but she only wrote on my school records on red ink, "She is undocumented." I thought my dreams would not end here. I knew that school was the only way for me to be successful. I went to a local college and was initially told I could not enroll because I was undocumented; but God was with me and he provided an angel willing to help me fulfill my dream.

These are the words of Sara, a now legal immigrant living in the United States, who came to this country at the age of twelve. Her story is one of personal tragedy and determination to achieve an education that she believed would change her life. Today, she has two Associates degrees and owns a successful 
business. In Sara's mind, her accomplishments are a result of personal persistence and the willingness of an "angel" to take a chance on her-the willingness of an educator to be an "outlaw."

This article discusses the marginalization of undocumented students at the secondary and post-secondary levels and, as a result, the creation of a movement on the part of transition counselors and higher education professionals to enact social justice, equity, and equality on behalf of these students. This movement-referred to as the creation of an "outlaw culture" (Evans, 2000) - is beginning to significantly reduce barriers as counselors and other educational allies are discovering these hidden networks. In this article, we define the terms of social justice, equality, and equity; engage in a review of the literature through presentation of judicial, legislative, and policy considerations; offer a theoretical framework for the outlaw culture phenomenon; and present six recommendations for education professionals and administrators on increasing access for undocumented students.

\section{Definitions and Review of Literature}

Adams, Bell, and Griffin (2007) described social justice as the "full and equal participation of all groups in a society that is mutually shaped to meet their needs" (p. 1). According to Varsanyi (2006), full membership in a society is situated within local communities, not state or federal entities; and undocumented immigrants are de facto members of their communities simply because of their presence within the space of the local community. Therefore, regardless of varying political perspectives regarding undocumented immigration, these students and their families are contributing members of their communities and thus share an equal stake in obtaining the full benefits granted to other members within U.S. society.

According to Espinoza (2007), equity is a concept "associated with fairness or justice in the provision of education or other benefits, and it takes individual circumstances into consideration" (p. 345). Educational equity for undocumented students ensures that resources, access, attainment, and outcomes are the same as documented students with similar needs, potential, and levels of achievement. Equality, on the other hand, "usually connotes sameness in treatment by asserting the fundamental or natural equality of all persons" (Espinoza, 2007, p. 345). In this instance, educational equality for undocumented students ensures that resources, access, attainment, and outcomes are the same as documented students regardless of individual needs or circumstances. Both equity and equality are necessary, fundamental aspects of attaining social justice for undocumented students. On one hand, those working toward equality might assist in eliminating the social, political, and cultural barriers that restrict undocumented students' equal access to educational 
opportunities. On the other hand, those working toward equity work toward designing and implementing policies for undocumented students, taking into consideration the reality of those social, political, and cultural barriers.

A variety of labels have been used to describe people who live in the U.S. who do not have proper legal documentation that would indicate that they are legal citizens of the United States. The term "unauthorized resident immigrant" is defined by Hoefer, Rytina, and Baker (2008) as "all foreign-born non-citizens who are not legal residents" (Unauthorized Residents section, para.1). Olsen (2009) states that immigrants are "outsiders" and that their diversity may appear to threaten dominant cultural, economic, and ideological conditions that have held their place in the American mainstream. Another term that is noted in legal and judicial language is "alien." "Alien" is defined as "relating, belonging, or owing allegiance to another country or government." (Merriam-Webster Online Dictionary, 2010) Yet, an additional definition of the label or term, "alien" is also noted as "differing in nature or character typically to the point of incompatibility." Perhaps, one's perspective regarding undocumented immigrants within the context of equality, equity, and social justice is found within one's allegiance to the first or second definition of the term "alien."

According to Passel (2006), approximately $12 \%$ of the population in the United States is comprised of immigrants. Of this $12 \%$, one-third does not have the legal status of citizenship in the U.S. During the period of 2000-2008, a $37 \%$ increase in the unauthorized immigrant population is noted, which equates to an increase of 3.1 million undocumented "aliens" (Hoefer, Rytina, \& Baker, 2008). The report authored by Hoefer, Rytina, and Baker (2008) out of the Office of Immigration Statistics for the Office of Homeland Security estimated that the states that grew most dramatically in regard to unauthorized immigrants were California (2.9 million), Texas (1.7 million), Florida (840,000), and New York $(640,000)$. The greatest percentage increases for unauthorized immigrants were found to be in the states of Georgia (105\%), Arizona (70\%) and Nevada (70\%). Approximately 1.8 million undocumented immigrants are under 18 years of age with an estimated 65,000 students graduating from public high schools in the U.S. annually.

At the federal level, the U. S. Supreme Court held that states could not deny undocumented students access to primary and secondary education under the $14^{\text {th }}$ Amendment and Equal Protection Clause of the U.S. Constitution by arguing that education serves the legitimate interests of the state. Specifically, the $14^{\text {th }}$ Amendment states: "Nor shall any State deprive any person of life, liberty, or property, without due process of law; nor deny to any person within its jurisdiction the equal protection of the laws."

The historical, judicial, and legislative chronology of the issues that have been confronted regarding access to higher education for undocumented 
students portrays the continued saga of conflict between those who have and those who have not. Within this context, the values of equity, equality, and social justice continue to be challenged between individuals, judicial, and legislative processes and institutional bureaucracies that create barriers to the true representation of these values within a democratic society. The ongoing frustrations for undocumented students, as well as those who work within the institutions that support these barriers, create a silent, underground wellspring of individuals who believe in the dignity of humanity and the potential of all persons regardless of status. Within these systems, "outlaws" find a way to beat the system and create individualized situations that are socially just.

\section{Judicial Considerations}

Undocumented immigrants come to the United States for various reasons. Some are seeking economic opportunity while others are leaving oppression and seeking a better way of life. As a society, the United States is faced with dilemmas and paradoxes associated with the migration of undocumented immigrants into the country. Does U.S. society imagine undocumented immigrants as part of the community and deserving of rights and responsibilities of our legal residents, or, are they simply violating the law and thus deserve limited status within society? These questions are particularly pertinent in the field of education. This section presents a review of legal and policy issues regarding undocumented immigrants in the U.S. education system.

Plyer v. Doe (1982) is one of the most prominent legal decisions regarding the education of undocumented immigrants. In this case, the legislature in the State of Texas legislature gave local schools the ability to deny access to children of undocumented immigrants. A lawsuit was filed sighting violation of the Equal Protection Clause of the Fourteenth Amendment. Texas law was upheld by both the district court and the court of appeals; however, the lower court ruling was overturned by the United States Supreme Court in June 1982, with Justice William Brennan writing the opinion (Drachman, 2006).

Justice Brennan's argument centers on the notion that it is unjust to hold students accountable for the actions of their parents. After all, these children had no choice in the decision to migrate to the United States. Further, to deny undocumented students access to higher education would severely inhibit possibilities for upward social mobility, and a college degree education is essential for participating in economic and political aspects of society. Of note, Justice Brennan did not indicate that education is a fundamental right, instead indicating a putative right to education (Yates, 2004). Yet, when speaking of the importance of education he explained: 
Illiteracy is an enduring disability. The inability to read and write will handicap the individual deprived of a basic education each and every day of his life. The inestimable toll of that deprivation on the social, economic, intellectual, and psychological wellbeing of the individual, and the obstacle it poses to individual achievement, make it most difficult to reconcile the cost or the principle of a status-based denial of basic education with the framework of equality embodied in the Equal Protection Clause. (Yates, 2004, p. 6)

While Plyler v. Doe addressed the issue of education for undocumented students at the elementary and secondary level, the approach to post-secondary education remained unchanged. Over the next fifteen years, the Supreme Court addressed issues of undocumented immigrants in higher education on several occasions. In the 1982 case of Toll v. Moreno, a Maryland statute preventing undocumented students from establishing residency was found to be unconstitutional. In 1990, the case of Regents of the University of California v. Bradford brought the issues of undocumented students in higher education to the attention of the court once again. Here, the court held that states may discriminate against undocumented immigrants, noting that higher education has a different status than elementary or secondary education (Yates, 2004).

In the case of Plyler v. Doe (1982), the U.S. Supreme Court held that a state statute might be consistent with the Equal Protection Clause of the $14^{\text {th }}$ Amendment if it presents a reasonable determination that supports a substantial state interest. To further support the rights of undocumented students, the U.S. Supreme Court in Plyler v. Doe (1982) made it clear that any state that denies education to an undocumented student based upon an argument of sustaining the benefits of legal residents would be in violation of the Equal Protection Clause.

Attaining an education supports a "substantial state interest" in terms of economic benefits as well as the sustainability of a democratic and socially just society. As noted in The Bell Policy Center Issue Brief (2005), the citation of a 1999 and 1995 RAND study indicated that an average 30-year-old Mexican immigrant woman with a college education would pay $\$ 5,300$ more in taxes with a reduced criminal justice and welfare cost of $\$ 3,900$. This creates an annual economic benefit to the state and federal interests of more than $\$ 9,000$ than if she dropped out of high school. Furthermore, a 3\% increase in the college graduation rate of 18-year-old Latinos would increase Social Security and Medicare contributions by $\$ 600$ million. Despite the plethora of research that supports the importance of education in every facet of societal benefit, access to higher education for undocumented students remains a controversial issue state by state.

\section{Legislative Considerations}


To address the issue of higher education access for undocumented immigrants, the federal government passed the Federal Illegal Immigration Reform and Immigrant Responsibility Act (IIRIRA) in 1996. Section 505 notes that:

\begin{abstract}
Notwithstanding any other provision of law, an alien who is not lawfully present in the United States shall not be eligible on the basis of residence within a State (or a political subdivision) for any postsecondary education benefit unless a citizen or national of the United States is eligible for such a benefit (in no less an amount, duration, and scope) without regard to whether the citizen or national is such a resident. (Federal Illegal Immigration Reform and Immigrant Responsibility Act, 1996)
\end{abstract}

Since its inception, this law has been the subject of much debate. While most states interpret it to mean that undocumented immigrants cannot receive in-state tuition rates, other states disagree. A review of the language notes the use of the word "unless," which many states interpret as a loophole allowing them to write legislation that provide benefits to undocumented immigrants will attempting to comply with the federal law (Drachman, 2006). Thus far, a total of eleven states have enacted legislation to allow unauthorized immigrant students to become eligible for in-state tuition if they meet certain requirements: California, Illinois, Kansas, Nebraska, New Mexico, New York, Oklahoma, Texas, Utah, Washington, and Wisconsin. However, in 2008, Oklahoma ended its support for in-state tuition rates for unauthorized alien students. These various laws possess the commonality of a requirement for students to be socially responsible in that they must be physical residents in good standing and state high school graduates who show intention to pursue legal residency. Specifically, each state permits qualifying students to be eligible for in-state tuition if they graduate from a within-state high school, can show proof of residing in the state from between two and three years, apply to that state's public college or university, and sign an affidavit promising to seek legal immigration status in all states except New Mexico. It is noted that these requirements are stricter than the standards for outof-state students who desire to change residency to gain access to in-state resident tuition status (Morse \& Birnbach, 2008).

Other states have barred or attempted to bar unauthorized immigrant students from in-state tuition benefits. Arizona Proposition 300 (as cited in Olivas, 2008) is a clear example. This 2006 initiative was passed and resulted in the removal of almost 5,000 students from in-state tuition status. In Georgia, a waiver system had allowed each public college to award in-state status to undocumented students for up to two percent of the college's headcount; however, in 2007 SB529, The Georgia Security and Immigration Compliance Act, took effect; and by 2008, undocumented students were unable to establish in-state residency in Georgia (Olivas, 2008). 
Although post-secondary institutions are less regulated by state and federal governance in comparison to primary and secondary school systems (Passel, 2006), the implementation of an in-state tuition benefit for undocumented students for higher education access continues to create controversy primarily at the legislative level. States continue to introduce and repeal legislation regarding in-state tuition for undocumented students; while at the federal level, the DREAM Act (Development, Relief and Education for Alien Minors) and its House version, the Student Adjustment Act, have remained in limbo until the recent re-introduction of the bill in the House and Senate on March 26, 2009 (National Immigration Law Center, 2009).

\section{Policy Considerations}

When discussing social justice in education, Gewirtz (2006) makes the argument that it is impractical to conceive of a policy that is "purely just." In practice, a policy that is equitable to one may neglect another in some form. Furthermore, Gewirtz makes that argument that the different definitions of social justice serve to create tension or a dynamic atmosphere when practitioners attempt to address issues from a social justice perspective. This tension is influenced by the norms and social constraints that practitioners experience on a daily basis (Gewirtz, 2006).

Similarly, this paper argues that it is unrealistic to believe that the issues of social justice, equity, and equality can create an evenhanded policy environment. However, we argue that when it comes to the practical application of education issues and policies, practitioners are not concerned about the multiple aspects of social justice. Rather, the primary concern is the balancing of social justice, equity, and equality with the concept of efficiency. A variety of mediating factors cause practitioners and policymakers to pursue the path of efficiency. This section discusses social justice, equity, and equality versus efficiency as applied to the issue of undocumented immigrants in higher education.

Those opposed to in-state tuition for undocumented immigrants argue that such policies are an inefficient use of taxpayer dollars. Specifically, critics note that within higher education the state government subsidizes in-state tuition. Allowing this subsidy to apply to undocumented immigrants moves resources away from native-born citizens of the state and of this country. The opposing view suggests that most undocumented immigrants interested in attending college are not likely to return to their native country (Kaushal, 2008).

Children of undocumented immigrants make up a significant portion of U.S. society. While not all these children will go to college, policies that restrict access to higher education rather than promoting access run the risk of creating a social underclass. It is appropriate to argue that the creation of the underclass 
has already started. The 2005 Current Population Survey (as cited in Kaushal, 2008 ) notes that $5 \%$ of undocumented Latino adults between the ages of 18 and 44 have a college education of any type, including associates degree or bachelor's degree. Further, many children of undocumented immigrants come from poor families that have limited means to assist with a college education (Kaushal, 2008). For these children access to higher education is particularly difficult when out-of-state tuition rates are sometimes three times that of in-state rates (Ruge \& Iza, 2005). Access to higher education also plays an important role in determining labor market outcome as those with a college education earn higher wages and are less likely to experience unemployment (Kaushal, 2008). Finally, various scholars are noting that investment in education decreases the cost that states must allocate to other social services (Kaushal, 2008; Levin, 2009).

States that continue to grapple with the issue of improving opportunities for undocumented immigrants to attend college may be focused on short-term political issues. Long term, the evidence suggests that this investment is an efficient use of taxpayer dollars. This investment also works to create a socially justice society and furthers the ideals of democracy inside the United States.

The line of efficiency versus social justice is very thin. There is a constant struggle among policy makers and educators to balance this issue. There are good people on both sides, passionate about their beliefs; yet all are wise to consider the words of John Dewey. In the book Democracy and Education (1944), Dewey notes that:

It is not enough to see to it that education is not actively used as an instrument to make easier the exploitation of one class by another. School facilities must be secure of such amplitude and efficiency as will in fact and not simply in name discount the effects of economic inequalities, and secure to all the wards of the nation equality of equipment for their future careers. (Dewey, 1944, p. 75)

Dewey asserts a social justice argument toward education policy versus one that focuses on efficiency. Another primary contention of Dewey is the importance of education to a democratic society. He notes that people who govern themselves must be educated and able to make the decisions necessary to preserve the democracy. This applies not just to a privileged few, but to all citizens in the society (Dewey, 1944).

Dewey has inspired a generation of education policy, and his approach has been both applauded and criticized.

In a recent article, Perry (2009) articulates a model for education policy in a democratic society. This model outlines five key points that are important 
when considering establishing socially just policies in educational arenas. The five key concepts are equality, diversity, participation, choice, and cohesion. When discussing equality, Perry notes that education plays a central role in social mobility in a democratic society. Thus, equal access and the opportunity for an equal outcome regarding education are paramount. The concept of diversity is centered on the notion of multiculturalism within education policy. Perry defines multiculturalism as an approach that fosters equal status for diverse groups and allowing those of various cultures to maintain their cultural identity rather than forcing assimilation into the dominant culture. A multicultural approach to education will promote a sense of equality among all cultures in an academic environment. Furthermore, it will give students confidences as they participate in a multicultural society, believing that their opinions and points of view are respected.

Participation and choice revolve around the principle that families and communities must be involved in education at the local level. Perry (2009) notes that involvement in the education policy process is critical in a democratic society. This involvement leads to choice for families regarding the education they want for their children and that young adults want for themselves. The concept of cohesion encompasses all the concepts in the model and speaks to the notion that education is critical to continuation of a democratic society. Education promotes identity regarding the values of how this country will move forward (Perry, 2009).

\section{Theoretical Framework}

As evidenced, current federal and state immigration laws do not aptly address the issue of access to higher education and the provision of legal paths to residency for undocumented students, despite the fact that many colleges knowingly admit these students (Mangan, 2009). As a result, many secondary and higher education administrators across the U.S. have begun to develop networks with one another and with scholarship-granting organizations that share a common commitment to reducing the financial, legal, and cultural barriers to a college education for undocumented students, most of whom entered the U.S. unknowingly as children. These higher educational professionals include the individual whom Sara referred to as an "angel" in the opening narrative. This particular "angel" assisted Sara in pursuing her academic dreams and making a way when no way seemed possible, thereby circumventing the rules and regulations that inhibited a socially just process for college access and that perpetuated inequity and inequality.

In juxtaposition to the notion of higher education professionals as angels, the recent development of these networks on the part of committed educators signals the creation of what Evans (2000) termed an "outlaw culture." 
In studying historical contexts of slavery through the lenses of feminist and critical race theories, Evans described African American women as "shapers and transmitters of a positive, outlaw culture, through which black women develop[ed] and formalize[d] strategies for coping with the terrifying exclusion of blacks from the protection of mainstream law" (p. 501). Today, undocumented students are similarly being excluded from protection of laws that would allow them to attend college without significant barriers; thus, a type of outlaw culture is being crafted at the post-secondary level to address the absence of social justice, equity, and equality.

While the term "outlaw" implies that one has broken or is continuing to break a particular law, in most cases outlaw culture more aptly refers to the creation of systems that function as law in the absence of a formalized legal structure. In other words, when there is no avenue for justice to be actualized, marginalized groups and their allies create the means through which social justice, equity, and equality are realized. Evans (2000) discussed the creation of black women's clubs in the late nineteenth and early twentieth centuries that sought to create avenues for social mobility for African Americans in the absence of such initiatives by mainstream society. These women "believed in adherence to the law and social order" (p. 505); and precisely because of those deeply-held beliefs, they created institutions outside the purview of mainstream law in order to pursue race and gender equity.

Therefore, in this context, outlaw culture is the creation of a support system that seeks social justice, equity, and equality for undocumented students. This calls for the institution of policies that grant undocumented students the right to pursue their higher educational dreams in a manner similar to those who benefit from full membership in U.S. society, namely, citizens born in this country. Perez (2009) asserted that denying undocumented students these full membership rights undermines the intent of the Constitution to protect individuals, not merely citizens or immigrants. Currently, equal access to education is only possible for these students through the public K-12 system.

Ultimately, outlaw culture demands social justice, equity, and equality for undocumented students in the sense that individuals must be able to engage fully in self-definition and self-determination. Evans (2000) argued that what black female outlaw culture ultimately worked to preserve was a sense of selfhood. Lack of comprehensive laws for former slaves, in very real ways, undermined the consideration of African Americans as human beings worthy of a lawful place in society. Therefore, a sense of self is crucial for members of outlaw communities because it provides a foundation from which persons can construct their own counternarratives (a concept originating in critical race theory) that can challenge dominant frameworks. Fan (1997) stated: 
"In stark contrast to traditional rights scholarship, critical race theory eschews the conventions of traditional interpretation and instead endeavors to recognize the voices of outsiders by employing the narrative form and by focusing on interrelationships of race, gender, and other identity characteristics." (p. 1204)

Counternarratives create the means through which those outside the law are able to gain legitimacy and personhood in dominant discourses. At the beginning of this article, Sara tells a portion of her own personal narrative regarding her experiences as an undocumented student. Sara's counter narrative not only legitimates those experiences, but also provides a critique to current legal structures by highlighting the inadequacy of current law to address and support her quest for social justice, equity, and equality.

\section{Implications for Practice}

Installing pathways to higher education and in-state tuition for undocumented students in the United States presents both opportunities and constraints in developing practices that promote social justice, equity, and equality. Those who are sympathetic to the challenges facing undocumented students may support opportunities to promote the potential of those who are deserving of incorporation and membership in U.S. society. On the other hand, proponents of tighter borders and tougher immigration laws may view all undocumented people, including model, hardworking young people, as "illegals" or temporary workers and consider them to be drains on the resources of society. This puts educational administrators in precarious positions since they are professionals who are trained to promote and support students in their pursuit of knowledge and self-improvement. Therefore, many professionals are left with little choice but to search for individuals and resources already established within outlaw cultures.

As a result of the prior research cited and discoveries of policy commitments and practices within varying outlaw cultures on this issue, we recommend the following six general and specific policies and practices that support access to higher education for undocumented students. In general, practitioners need to weigh opportunities against constraints and consider the potential opportunities to promote social justice, equality, and equity in higher education access. Rather than considering undocumented students as "illegals" and restricting their access to legitimate educational pathways, it is recommended that, at the very least, those in positions of power adopt an outlaw cultural framework to support the strengths inherent within diversity as well as pursue avenues of social justice for undocumented students who are seeking to access higher education to improve their future and secure permanent membership in U.S. society. 
1. It is equitable and just that those undocumented students who meet strict residency and high school graduation qualifications should be granted in-state tuition to public colleges and universities. Undocumented students are individuals deserving of opportunity and access who bring the strength of their diverse experiences and cultures to our society. Incorporation and inclusion empowers these educational stakeholders to become key players in our communities.

2. From a policy perspective, states with current in-state tuition allowances should research, publish, disseminate, and communicate information regarding the success and failures of their programs and the impact of their practices on budgets, communities, and individuals. This information is critical in gaining support for similar policies and practices in other states. Information regarding specific practices in states that have enacted legislation should be archived and disseminated from a central location creating a database of successful strategies to support those who seek to promote social justice, equality and equity for undocumented students.

3. Higher education administrators should promote access opportunities through their various appearances, professional affiliations, and influences in the community. Higher education administrators should be particularly knowledgeable and resourceful. The very foundation of public higher education is open access and open admissions. Many presidents, chancellors, etc. affect the practices of their regions and states. Utilizing research-based data, higher education administrators will be able to present the positive win/win scenario that highlights the successes of undocumented students and the positive impact of these successes upon the economic, social and political elements of the greater society.

4. Higher education administrators should stay abreast of legal issues and adopt practices that promote inclusion by asserting themselves as proponents of opportunity for all. It is important that registrars, counselors, and recruiters have access to information regarding scholarships and community organizations that can help undocumented students gain access and knowledge of the pathways toward scholarships and other funding opportunities. The families of students need to be provided information that may help them make the best choices with and for their children.

5. Higher education administrators should establish support systems to overcome the challenges faced in sustaining effective grade school/family and workforce/community partnerships. Parents, families, and school personnel alike must sometimes overcome a large array of internal and external challenges to promote change and transformation. As these key players explore together ways to overcome these challenges, non-threatening avenues of communication must be open to them. 
6. Frequent and thoughtful communication matters. Establishing and maintaining community partnerships is a social, political, and administrative responsibility, which involves multiple parties with diverse perspectives. Practitioners should exercise creative strategies to make information about partnerships (for example, studies that focus on innovative, exemplary practices and programs) available to stakeholders involved in education equality and reform. Talking about successes of programs and their students helps initiate a dialog about the benefits of programs that promote social equity and opportunity for advancement.

7. Exemplar practices designed to help undocumented students through transitions, difficulties, and struggles with cultural identity and acceptance in their communities may be found in several western states. At Glendale Community College in California (Zariani, 2008), undocumented students achieve the status of $A B 540$ students (after the legislation allowing them in-state tuition inclusion), thus giving them legitimacy and a sense of place in the campus community. Jauregui, Slate, and Brown, (2008) write of successes of undocumented students' in Texas Community Colleges and describe the efforts in Texas to ease these students' fears of deportation, feelings of loneliness, and depression. Gonzalez (2008) describes the effect of AB 540 in California allowing more educational and civic opportunity for activism. In California, both legal residents and AB 540 students are becoming active in promoting the authorization of the participation and existence of students who oftentimes don't have a drivers' license, voter registration, or any other proof of legitimacy even after having "grown up American" (Gonzalez, 2008, p. 225).

In Colorado, where recent legislation that would allow an in-state tuition opportunity for undocumented students failed, a community-minded group of student services professionals volunteer their personal time to make presentations to provide information on immigrant students and higher education to those interested. In return, they ask for support for travel and mileage and donations for scholarships for Colorado Students. As an example, Metropolitan State College of Denver's extended campuses in Westminster and the Denver Tech Center offer "flat rate" tuition, making enrollment a viable possibility for undocumented students in the area. Programs and practices in the nine "immigrant student friendly" states as well as in those states such as Colorado, which strives to obtain a more inclusive tuition policy, are valuable examples for any state wishing to increase diversity and inclusiveness.

These six recommendations from grassroots outlaw culturalists are simple policy and practice commitments that can assist in providing increased social justice, equality, and equity for undocumented students. These actions imply that both policymakers and practitioners must think and act somewhat like outlaws, in creative and different ways than they have done in the past. As educators and community members, we all must act responsibly to promote 
legal, equal, equitable and socially just pathways to include undocumented students in higher education.

\section{Conclusion}

This article transitions from the individual impact, as in Sara's narrative, to the more complex societal implications regarding access, or lack thereof, to higher education for undocumented students. Regardless of the context of the individual or the greater society, values of social justice, equity, and equality are critical considerations within the individual judicial, legislative, and policy frameworks noted. As members of a democratic society, we must delve deeply into our beliefs in relation to the beliefs of those responsible for crafting the Constitution and determine whether liberty and justice for all really does include all people. Whether those who choose to commit to socially just action to support access to higher education for undocumented students are considered to be "angels" or "outlaws," the ultimate authority lies in the hearts and minds of those with a different sort of access - those with access to power and privilege. It is within these power structures that access to a life of quality is denied or granted. These decisions cannot be carelessly determined by the waves of political clout and gain, but rather from a value-based framework that encapsulates social justice, equity, and equality for all.

\section{References}

Adams, M., Bell, L. A., \& Griffin, P. (Eds.). (2007). Teaching for diversity and social justice (2nd ed.). New York, NY: Routledge.

Alien (2010). In Merriam-Webster Online Dictionary. Retrieved from http:www.merriam-webster.com/dictionary.alien

College Board. (n.d.). Advising undocumented students: Higher education obstacles and possibilities. Retrieved from http://professionals.collegeboard.com/guidance/financial-aid/undocumentedstudents

Dewey, J. (1944). Democracy and education. New York: The Echo Library (reprint in 2007).

Drachman, E. (2006). Access to higher education for undocumented students. Peace Review: A Journal of Social Justice, 18(1), 91-100.

Espinoza, O. (2007). Solving the equity-equality conceptual dilemma: A new model for analysis of the educational process. Educational Research, 49(4), 343-363.

Evans, M. J. (2000). Stealing away: Black women, outlaw culture, and the rhetoric of rights. In R. Delgado \& J. Stefancic (Eds.), Critical race theory: The cutting edge (2nd ed., pp. 500-513). Philadelphia, PA: Temple University Press. 
Fan, S. S. (1997). Immigration law and the promise of critical race theory: Opening the academy to the voices of aliens and immigrants. Columbia Law Review, 97(4), $1202-1240$.

Federal Illegal Immigration Reform and Immigrant Responsibility Act of 1996, Pub L. 104-208. (1996). Georgia Security and Immigration Compliance Act, Off. Code of GA Ann. 13-10.2-3. (2007).

Gewirtz, S. (2006). Towards a contextualized analysis of social justice in education. Education Philosophy and Theory, 38(1), 69-81.

Gonzales, R. G. (2008). Left out but not shut down: Political activism and the undocumented student movement. Northwestern Journal of Law and Social Policy 3, 219-239.

Hoefer, M., Rytina, N., \&Baker, B.C. (2009). Estimates of unauthorized immigrant population residing in the United States: January 2009. Retrieved from http://www.dhs.gov/xlibrary/assetts/statistics/publications/ois_ill_pe_2009.pdf

Jauregui, J. A., Slate, J. R., Brown, M. S. (2008). Texas community colleges and characteristics of a growing undocumented student population. Journal of Hispanic Higher Education, 7(4), 346-355.

Kaushal, N. (2008). In-State tuition for the undocumented: Education effects on Mexican young adults.

Journal of Policy Analysis and Management, 27(4), 771-792.

Levin, H. M. (2009). The economic payoff to investing in educational justice. Educational Researcher, 38(1), 5-20.

Mangan, K. (2009, March 17). Most colleges knowingly admit illegal immigrants as students, survey finds. The Chronicle of Higher Education. Retrieved from $\mathrm{http} / / /$ chronicle.com/article/Most-Colleges-Knowingly-Admit/42575/

Morse, A., \& Birnbach, K. (2008, November 30). In-state tuition and unauthorized immigrant students. National Conference of State Legislatures. Retrieved from http://www.ncsl.org/default.aspx?tabid=13100

National Immigration Law Center, DREAM Act: Basic Information. (2009). Report on basic information regarding the DREAM Act. Retrieved from http:www.nilc.org/immlawpolicy/dream/dream-basic info-2009-03-30.pdf

Olivas, M. A. (2008). Perspectives: Colleges and undocumented students. Change - The Magazine of Higher Learning.

Olsen, L. (2009). The role of advocacy in shaping immigrant education: A California case study. Teachers College Record, 111(3), 817-850.

Passel, J. (2006). Size and characteristics of the unauthorized migrant population in the U.S.: Estimates based on March 2005 current population survey. Retrieved from http://pewhispanic.org/files/report/61.pdf

Plyler v. Doe, 457 U.S. at 2167-218 (1982).

Protopsaltis, S. (2005). Undocumented immigrant students and access to higher education: An overview of federal and state policy. The Bell Policy Center: Issue Brief, 1-14.

Perez, W. (2009). We are Americans: Undocumented students pursuing the American dream. Sterling, VA: Stylus.

Perry, L. B. (2009). Conceptualizing education policy in democratic societies. Educational Policy, 23(3), 423-450. 
Proposition 300, Arizona Revised Statute. 15-1825 (2006).

Regents of the Univ. of Cal. v. Bradford, 276 Cal.Rptr. 197, 198 (1990).

Ruge, T. R., \& Iza, A. D. (2005). Higher education for undocumented students: The case for open admission and in-state tuition rates for students without lawful immigration status. Indiana International and Comparative Law Review, 15(2), 257-278.

Toll v. Moreno, 458 U.S. 1 (1982).

Varsanyi, M. V. (2006). Interrogating "urban citizenship" vis-à-vis undocumented migration. Citizenship Studies, 10(2), 229-249.

Yates, L. S. (2004). Plyer v. Doe and the rights of undocumented immigrants to higher education: Should undocumented students be eligible for in-state college tuition rates? Washington University Law Quarterly, 82(2), 585-609.

Zariani, H. (2008). Barriers to civic engagement for undocumented students. Diversity \& Democracy,11(2), 